\title{
Design discharge estimation in small and ungauged basins: EBA4SUB framework sensitivity analysis
}

\author{
Andrea Petroselli, ${ }^{1}$ Rodolfo Piscopia, ${ }^{2}$ Salvatore Grimaldi ${ }^{3}$ \\ ${ }^{1}$ DEIM Department, Tuscia University, Viterbo (VT), Italy; ${ }^{2}$ Freelance, Rome (RM), Italy; ${ }^{3}$ DIBAF Department, Tuscia \\ University, Viterbo (VT), Italy
}

\begin{abstract}
The design hydrograph and the related peak discharge estimation for small and ungauged basins is a common problem in practical hydrology. When discharge observations are not available, it is difficult to calibrate physically-based hydrological models that are typically characterized by a large number of input parameters. Recently, a simple empirical-conceptual rainfall-runoff model called EBA4SUB (event-based approach for small and ungauged basins) has been proposed. Its advantages are a limited user subjectivity, the employment of advanced hydrologic modules, and the use of input data similar to the information necessary for applying the well-known rational formula. In this contribution we illustrate the EBA4SUB sensitivity analysis, in order to assess the input parameters influence on the output design discharge. Results showed, as expected, that the most effective parameter is the curve number, followed by the concentration time. On the contrary, the threshold area value for classifying the drainage network, the time resolution of the design hyetograph and of the unit hydrograph, and the kinematic parameters needed to estimate the flow time can be considered as ancillary input parameters.
\end{abstract}

\section{Introduction}

The design flood hydrograph estimation is still a crucial issue in practical hydrology, in particular in small and ungauged basins, where discharge observations are lacking and the application and

Correspondence: Andrea Petroselli, DEIM Department, Water Engineering Section, Tuscia University, Via S. Camillo de Lellis snc, 01100 Viterbo (VT), Italy.

Tel.: +39.0761.357348 (direct) - Fax: +39.0761.357250.

E-mail: petro@unitus.it

Key words: Design peak discharge; EBA4SUB: rainfall-runoff modeling: ungauged basin.

Received for publication: 11 December 2019.

Accepted for publication: 20 February 2020.

(C) Copyright: the Author(s), 2020

Licensee PAGEPress, Italy

Journal of Agricultural Engineering 2020; LI:1040

doi:10.4081/jae.2020.1040

This article is distributed under the terms of the Creative Commons Attribution Noncommercial License (by-nc 4.0) which permits any noncommercial use, distribution, and reproduction in any medium, provided the original author(s) and source are credited. calibration of sophisticated hydrological models is unviable.

When a statistical analysis on observed discharge data cannot be performed, indirect methods are adopted, like regionalization approaches, empirical formulas, or rainfall-runoff models (Młyński et al., 2018). However, it is noteworthy that regionalization approaches are often approximate due to the limited data on the peak flow size in gauged donor catchments, while the error associated with the use of empirical formulas is often significant; therefore, a recommended practice is the use of rainfall-runoff models (Gądek et al., 2017).

In the last twenty years, the International Association of Hydrological Sciences - Prediction in Ungauged Basins initiative (IAHS-PUB; Sivapalan et al., 2003) paved the way for a number of scientific contributions aiming in predicting hydrological processes in catchments without discharge observations, and different rainfall-runoff models have been proposed, but hydrologists still struggle in choosing the most appropriate one.

Analysis of recent literature reveals that many countries worldwide deal with this issue adopting different strategies. For instance, in Europe we report the approaches applied in Poland, where rainfall-runoff models like the Nash cascade of linear reservoirs, the geomorphological unit hydrograph, or the Snyder synthetic unit hydrograph are diffused (Wałęga, 2016), and in Slovakia, where is common to use an empirical method based on the basin morphometric parameters coupled with both regional factors, derived for specific areas of the country, and the SCS Dimensionless Unit Hydrograph (Vojtek and Vojteková, 2016).

In Asia, in China, semi distributed hydrological models have been extensively used, but one of the main challenges that remains unsolved is finding appropriate model parameter values for ungauged catchments (Xu et al., 2018); in Iran, different hydrologic models incorporating catchment geomorphological properties (e.g. Nash IUH, SCS UH, ANN, hybrid artificial intelligence based models) are commonly applied (Sabzevari, 2017).

In Africa, in Gabon, simple rainfall-runoff models coupled with the Muskingum routing approach have been used, since it is recognized that lumped conceptual models can provide good results in spite of the reduced complexity (Kittel et al., 2018); in Zimbabwe, rainfall-runoff models such as the Snyder Unit Hydrograph method are commonly used for ungauged catchments predictions based on parametrical assimilation from gauged catchments (Gumindoga et al., 2017).

In America, specifically in Brazil, are preferred conceptual rainfall-runoff models whose parameters are calibrated on synthetic long-term flow duration curves (Pinheiro and Naghettini, 2013); in Canada, systematic combinations of watershed classification techniques, regionalization methods, and rainfall-runoff models are commonly adopted (Razavi and Coulibaly, 2017); finally, in USA, regional regression equations are developed to correlate physical and climatic characteristics to the parameters of the more employed rainfall-runoff models usually (Clark et al., 2017) and graphical peak discharge method can be used to asses 
design peak discharges (Wałęga et al. 2020).

The above reported literature review, synthetically reported in Table 1, reveals that there is a spread use of empirical-conceptual rainfall-runoff models. Actually, from an ungauged basin point of view, simple conceptual models are more attractive, grasping the complex mechanisms governing the catchment response following the principle of parsimony. Conversely, the majority of complex hydrological models include several parameters that can hardly be estimated in ungauged basins, making unviable their practical application in such locations.

Recently, the event-based approach for small and ungauged basins (EBA4SUB) empirical-conceptual rainfall-runoff model has been proposed (Piscopia et al., 2015; Petroselli and Grimaldi, 2018). The model includes a sequence of modules typical of the event-based procedures: design gross rainfall estimation, excess rainfall estimation, and rainfall-runoff transformation. The main aim of EBA4SUB is to setup a framework that provides very similar results when it is applied by two analysts at different times for the same case study, minimizing the user subjectivity.

EBA4SUB has been applied in several contributions (Recanatesi et al., 2017; Nardi et al., 2018; Młyński et al., 2018; Petroselli et al., 2019a, 2019b, 2019c; Vojtek et al., 2019) where various small watersheds, located in different countries and with different geomorphologic characteristics as well as different climatic regimes, have been analysed giving proficient results.

The aims of this study is to provide a parameter sensitivity analysis of EBA4SUB model, in order to determine the primary and ancillary parameters, suggesting also default values to be used by the modeler in practical applications.

\section{Materials and methods}

\section{Case studies}

Four case studies have been selected and analysed. Two are located in Italy, one in Bosnia and Herzegovina and one in Iran. In Figure 1 locations of the case studies are shown and in Table 2 their general characteristics are reported. Case studies are ordered for increasing total contributing area and their main characteristics are described as in the following: i) Vezza river watershed (catchment area $167.9 \mathrm{~km}^{2}$ ), tributary of the Tiber River, located in central Italy. Elevations range from $63 \mathrm{~m}$ to $1052 \mathrm{~m}$, and the average slope is around $10 \%$. The watershed DEM at $20 \mathrm{~m}$ spatial resolution was provided by the Italian Geographic Military Institute (IGMI), land cover was extracted from the CORINE database, and soil data has been derived from the soil map provided by the local administration. Main land uses are non-irrigated arable land $(48 \%$ of the catchment area), complex cultivations (15\% of the catchment area) and broad-leaved forest (14\% of the catchment area). Observed annual maxima of cumulative rainfall data for different durations (from 1 to 24 hours) are available, provided by Lazio region Agenzia Regionale di Protezione Civile - Centro Funzionale Regionale, for the Viterbo rain gauge station, located $15 \mathrm{~km}$ from the catchment centroid, for a period of 71 years (from 1928 to 2015, with interruptions); ii) Gornji Vakuf river watershed (catchment area $207.9 \mathrm{~km}^{2}$ ), tributary of Vrbas river, located in the central part of Bosnia and Herzegovina. Elevations range from $666 \mathrm{~m}$ to 2183 $\mathrm{m}$, and the average slope is around $27 \%$. DEM at $50 \mathrm{~m}$ resolution was retrieved thanks to Federal Administration for Geodetic and

Table 1. Common methods applied worldwide.

\section{Common methods (not exhaustive list)}

Europe

Nash cascade of linear reservoirs, GIUH models, Snyder synthetic UH, empirical methods, SCS UH

Asia Nash IUH, SCS UH, Artificial Neural Network, hybrid artificial intelligence based models

Africa

Lumped conceptual models, Snyder synthetic UH

America Conceptual rainfall-runoff models, regionalization methods, graphical peak discharge method

Table 2. Case studies general characteristics.

\begin{tabular}{|c|c|c|c|c|}
\hline & Vezza & Gornji Vakuf & Abolabbas & Dittaino \\
\hline Catchment Area $\left(\mathrm{km}^{2}\right)$ & 167.9 & 207.9 & 282.5 & 397.9 \\
\hline Minimum Elevation (m) & 63 & 666 & 680 & 219 \\
\hline Average Elevation (m) & 338 & 1303 & 1880 & 492 \\
\hline Maximum Elevation (m) & 1052 & 2183 & 3300 & 1183 \\
\hline Main River Length (km) & 32.4 & 29.6 & 40.5 & 31.9 \\
\hline Average Catchment Slope (\%) & 9.9 & 27.3 & 40.3 & 15.5 \\
\hline Hydrological Soil Group & B & B & $\mathrm{C}$ & B \\
\hline Topographic information & DEM 20m, IGMI & DEM 50m, FGU & DEM 30m, ASTER & DEM 20m, IGMI \\
\hline Land Cover information & CORINE Program & CORINE Program & $\begin{array}{c}\text { Forests, Range and } \\
\text { Watershed Management } \\
\text { Organization of Iran }\end{array}$ & CORINE Program \\
\hline Soil information & $\begin{array}{l}\text { Digitized from local } \\
\text { Authorities maps }\end{array}$ & $\begin{array}{l}\text { Federal Institute } \\
\text { of Agropedology }\end{array}$ & $\begin{array}{l}\text { Forests, Range and Watershed } \\
\text { Management Organization of Iran }\end{array}$ & $\begin{array}{l}\text { Digitized from local } \\
\text { Authorities maps }\end{array}$ \\
\hline Rainfall data & $\begin{array}{c}\text { Regione Lazio, } \\
\text { Centro Funzionale } \\
\text { Regionale } \\
\end{array}$ & $\begin{array}{c}\text { Federal } \\
\text { Hydrometeorological } \\
\text { Institute of Sarajevo }\end{array}$ & $\begin{array}{l}\text { Iran Water Resources } \\
\text { Management Company }\end{array}$ & $\begin{array}{c}\text { Regione Sicilia, } \\
\text { Dipartimento Regionale } \\
\text { di Protezione Civile } \\
\end{array}$ \\
\hline
\end{tabular}


Property Affairs (FGU) in Federation of Bosnia and Herzegovina, CORINE program was used for land cover, and soil type was digitized using 1:50.000 scale maps available on web site of Federal Institute of Agropedology. Main land uses are broad-leaved forest ( $49 \%$ of the catchment area), natural grassland (14\% of the catchment area) and pastures (10\% of the catchment area). Daily data from 1949 to 2016 plus hourly data from 1981 to 2016 recorded by Bugojno raingauge have been used. The data were retrieved thanks to Federal Hydrometeorological Institute of Sarajevo; iii) Abolabbas river watershed (catchment area $282.5 \mathrm{~km}^{2}$ ), located in the east of Khuzestan province, Iran. In this watershed the elevation varies from $680 \mathrm{~m}$ to $3300 \mathrm{~m}$, with an average basin slope equal to $40 \%$. A DEM at $30 \mathrm{~m}$ resolution was downloaded from ASTER GDEM website (https://asterweb.jpl.nasa. gov/gdem.asp). Land cover and soil maps were retrieved thanks to Forests, Range and Watershed Management Organization of Iran. Main land uses are broad-leaved forest ( $46 \%$ of the catchment area) and agro-forestry areas $(45 \%$ of the catchment area). Regarding rainfall data, DepthDuration-Frequency (DDF) curves, based on a multiyear analysis on maximum values recorded for the durations of 15, 30, 45 min-
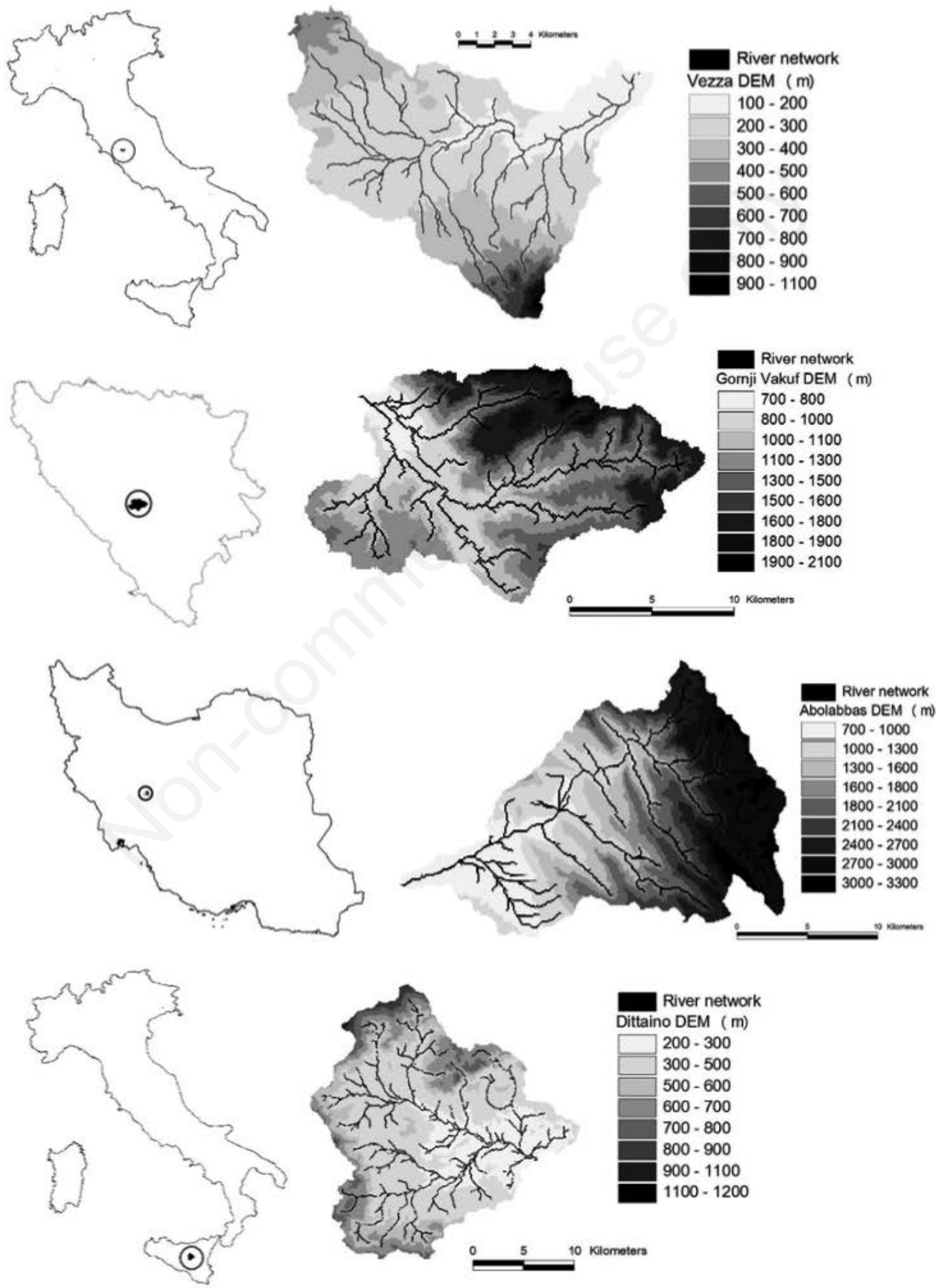

River network

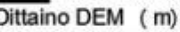

$200-300$

$300-500$

$500-600$

$600-700$

$700-800$

$800-900$

$900-1100$

$1100-1200$

Figure 1. Case studies localization. DEMs and drainage networks are shown. 
utes and 1, 2, 3, 4, 5, 6, 9, 12, 18, 24, 36 and 48 hours, were provided by Iran Water Resources Management Company for three raingauges near the case study area; iv) Dittaino river watershed (catchment area $397.9 \mathrm{~km}^{2}$ ), tributary of Simeto river, located in Sicily, South Italy. In this watershed the elevation varies from $219 \mathrm{~m}$ to $1183 \mathrm{~m}$, with an average basin slope equal to $15 \%$. As for the Vezza case study, the watershed DEM at $20 \mathrm{~m}$ spatial resolution was provided by the Italian Geographic Military Institute, land cover was extracted from the CORINE database, and soil data has been derived from the soil map provided by the local administration. Main land uses are Non-irrigated arable land (63\% of the catchment area) and complex cultivation (10\% of the catchment area). Regarding rainfall data, Depth-Duration-Frequency (DDF) curves were provided by Regione Sicilia, Dipartimento Regionale di Protezione Civile, related to Leonforte raingauge station, located inside the study area.

\section{The EBA4SUB model}

As premised, EBA4SUB model has been developed with the aim of determining the design hydrograph and related peak discharge in ungauged basins, optimizing the catchment topographic information and using the same information necessary to apply the well-known rational formula. EBA4SUB consists in the following modules: gross rainfall estimation, excess rainfall estimation, and excess rainfall-direct runoff transformation.

In the gross rainfall module, observed rainfall events recorded at raingauge can be loaded as design hyetographs; alternatively, depth-duration-frequency (DDF) curves may be used, specifying the critical rainfall duration and the design hyetograph pattern between the rectangular, triangular, or Chicago. Areal reduction factor (ARF) can be applied in order to transform the point raingauge information in a spatially uniform rainfall assigned to the whole catchment. Regarding the critical rainfall duration, by default EBA4SUB first estimates the basin concentration time $\left(T_{c}\right)$ using the Giandotti formula, retrieving necessary information from the basin's DEM. The rainfall duration is therefore set by default equal to $T_{c}$. Nonetheless, rainfall duration can be varied by the user according to any desired duration, chosen arbitrarily or computed by using a different empirical formula for $T_{c}$.

In the excess rainfall estimation module, the curve number for Green-Ampt (CN4GA) procedure is applied, consisting in two steps: the first step uses the empiric curve number $(\mathrm{CN})$ method (NRCS, 2008) to determine ponding time and cumulative excess rainfall volume starting from cumulative gross rainfall volume adopting the following equation:

$$
\begin{array}{ll}
P_{e}=\frac{\left(P-I_{a}\right)^{2}}{P-I_{a}+S} & \text { if } P>I_{a}=\lambda S \\
P_{e}=0 & \text { if } P \leq I_{a}=\lambda S
\end{array}
$$

where $P_{e}(\mathrm{~mm})$ is the cumulative excess rainfall, $P(\mathrm{~mm})$ is the cumulative gross rainfall, $I_{a}(\mathrm{~mm})$ is the initial abstraction, $\lambda(-)$ is the initial abstraction ratio and $S(\mathrm{~mm})$ is the soil potential retention related to the $\mathrm{CN}$ value.

The second step distributes the cumulative excess rainfall volume in time, within the assumed event duration and with the desired sub-event resolution, according to the physically based Green-Ampt (GA) equation, calibrating automatically the equation parameters:

$$
\begin{array}{ll}
q_{0}(t)=K_{s}\left(1+\frac{\Delta \theta \Delta H}{I(t)}\right) & \text { if } t>t_{p} \\
q_{0}(t)=i(t) & \text { if } t \leq t_{p}
\end{array}
$$

where $q_{0}(\mathrm{~mm} / \mathrm{h})$ is the infiltration rate, $i(\mathrm{~mm} / \mathrm{h})$ is the gross rainfall intensity, $I(\mathrm{~mm})$ is the cumulative infiltration, $K_{S}(\mathrm{~mm} / \mathrm{h})$ is the saturated hydraulic conductivity, $t_{p}(\mathrm{~h})$ is the ponding time, $\Delta H$ $(\mathrm{mm})$ is the difference between the matric pressure head at the moving wetting front and at the soil surface and $\Delta \theta(-)$ is the change in soil water content between the initial value of soil water content $\left(\theta_{i}\right)$ and the field saturated soil water content $\left(\theta_{s}\right)$. CN4GA is implemented assuming that the ponding time occurs when total gross rainfall equals to the initial infiltration as assumed in $\mathrm{CN}$ method. From a practical point of view, the cumulative excess rainfall is first estimated using Eq. (1) with $\lambda=0.2$ and $\mathrm{CN}$ obtained from look up tables linking $\mathrm{CN}$ and soil type/land cover maps. By difference, the $\mathrm{CN}$ cumulative infiltration is quantified. It has to be noted that ponding time is assumed as the time when $P(t)=I_{a}$, and excess rainfall is null until $P(t)<I_{a}$. Then, the cumulative infiltration is computed by Eq. (2), where the parameters of Green-Ampt equation are tentatively assumed equal to those reported in literature for the considered specific soil type. Finally, the infiltrations estimated by GA and $\mathrm{CN}$ are compared: three cases can occur.

First, infiltrations are equal (tolerance is set as $0.1 \mathrm{~mm}$ ) and CN4GA reached the convergence.

Second, if GA gives infiltration higher than the CN one, Eq. (2) is solved again using a lower value for effective saturated hydraulic conductivity. Such value is iteratively reduced by a delta until GA gives infiltration lower than that obtained by CN. In this case, delta is smoothly reduced to give finer convergence to the iterative procedure.

Third, if GA gives infiltration lower than the CN one, Eq. (2) is solved again using a higher value for effective saturated hydraulic conductivity value, and this value is iteratively increased by until GA gives infiltration higher than $\mathrm{CN}$ infiltration. In this case, delta is smoothly reduced to give finer convergence to the iterative procedure. At the convergence of the iterative procedure, a calibrated value for the effective saturated hydraulic conductivity is quantified. According to the previous step, excess rainfall is null until ponding time. Consequently, by applying Eq. (2) with the calibrated saturated hydraulic conductivity parameter, the CN4GA rainfall excess is obtained. This synthetic event has the same cumulative rainfall excess value and the same initial abstraction value derived with the $\mathrm{CN}$ method, but it has a physically based time distribution.

In the excess rainfall-direct runoff transformation module, the width function-based instantaneous unit hydrograph (WFIUH1par) is applied. WFIUH-1par is a kinematic-based model that estimates the distribution of travel time from any DEM cell to the outlet considering the surface flow velocity, both in river network and hillslope cells, as expressed by:

$$
W F I U H(t)=\frac{L_{c}(x)}{v_{c}(x)}+\frac{L_{h}(x)}{v_{h}(x)}
$$

where $L_{c}$ and $L_{h}$ are the drainage path in the channel and along the hillslope, respectively, corresponding to the DEM cell $x$, and $v_{c}$ and $v_{h}$ the assumed velocity values over the channel and hillslope cells, respectively. 
In detail, DEM is first preprocessed in order to remove spurious points such as pits and flat areas (Petroselli and Fernandez Alvarez, 2012), runoff paths are determined for each location of the basin along the DEM-controlled flow direction, and the river network is extracted using the threshold area criterion. Second, the hillslope flow velocities are defined for each pixel employing a formula linking velocity to local slope and land cover. Third, runoff lengths are rescaled using the corresponding flow velocities in order to obtain the probability distribution of the time required for rainfall drops to reach the basin outlet. Hillslope pixels are associated to the flow velocity defined as in above, while for the channel pixels the drainage network velocity is calibrated imposing that the WFIUH mass centre is equal to the basin lag time $\left(\mathrm{T}_{\mathrm{L}}\right)$, which is estimated as the $60 \%$ of the concentration time $\left(\mathrm{T}_{\mathrm{c}}\right)$, that is automatically determined by the model employing the Giandotti formula. Finally, the design hydrograph $Q(t)$ and the corresponding design peak discharge $Q_{p}$ are estimated computing the convolution integral between WFIUH and excess rainfall using the following:

$$
Q(t)=A \int_{0}^{t} W F I U H(t-\tau) \cdot P_{n}(\tau) d \tau
$$

where $A\left(\mathrm{~km}^{2}\right)$ is the basin contributing area, $t(\mathrm{~h})$ is the rainfall duration, $\tau$ is the time step in precipitation duration $(\mathrm{h}), P_{n}(\tau)(\mathrm{mm})$ is the excess rainfall determined with CN4GA method.

From a methodological point of view, EBA4SUB is characterized by two main advantages. First, for excess rainfall estimation, it combines the simplicity of an empirical approach with the accuracy of a physically based infiltration scheme. Second, for excess rainfall-direct runoff transformation, the IUH shape is determined using detailed geomorphological information on every basin pixel avoiding the use of synthetic shapes.

\section{EBA4SUB input parameters and sensitivity analysis}

In this contribution, we focus on the design peak discharge values obtained with EBA4SUB as respect to the assumed values of input parameters. From a practical point of view, for each input parameter we set a plausible range of possible values and a refer- ence value within the range. In order to assess the EBA4SUB sensitivity we consider a dimensionless Sensitivity Index between the Upper and Lower extremes values (SIUL) of the predefined range. SIUL expresses the relative change in the design peak discharge, compared to the reference solution, divided by the relative change in the input for a specific input parameter, and it can be defined using the following relation:

$$
S I_{U L}=\frac{\Delta O / O_{0}}{\Delta P / P_{0}}=\frac{\frac{O_{U}-O_{L}}{O_{0}}}{\frac{P_{U}-P_{L}}{P_{0}}}
$$

where $\Delta P$ is the change in the parameter vector $P$ due to a change in the single $i$-th parameter $p_{i} ; P_{U}$ and $P_{L}$ are the parameter extreme values defined selecting upper and lower values of the generic parameter $p_{i}$ while the other input parameters are held constant at their reference values; $O_{0}$ is the examined output variable obtained using the reference values for the parameter set $P_{0}$, and symbols $O_{U}$ and $O_{L}$ represent the model output corresponding to the parameter set with the selected upper and lower bounds of parameter $p_{i}$. For example, parameter vector $P_{1, U}$ is equal to $\left\{p_{1, U} ; p_{2,0} ; p_{3,0}\right.$; $\ldots\}$, with $p_{1, U}$ being the upper value for parameter $p 1$ and $p_{2,0}, p_{3,0}$ $\ldots$ being the reference values for parameters $p_{2}$, $p_{3}$, and so on.

In order to provide a simple judgment on the sensitivity of the single input parameter, we classified the obtained values in the following classes, employing the methodology followed by Feki et al. (2018): for $0 \%<\mid$ SIUL $\mid<10 \%$ we refer to a sensitivity from small to negligible, for $10 \%|\mathrm{SIUL}|<20 \%$ we refer to a medium sensitivity, for $20 \% \mid$ SIUL $\mid<100 \%$ we refer to a high sensitivity, and for $\mid$ SIUL $\mid>100 \%$ we refer to a very high sensitivity.

In the following analysis, $Q_{p}$ will be set as the examined output variable. Both the range and reference input parameters are reported in Table 3, according to what aforementioned in previous paragraph.

In what follows we synthetically describe the meaning of the input parameters.

The catchment concentration time $\left(T_{c}\right)$ determines (if not dif-

Table 3. EBA4SUB model input parameters.

\section{EBA4SUB input parameters}

TC Concentration time

l Initial abstraction ratio

CN Curve Number

$K_{S} \quad$ Saturated hydraulic conductivity

$\theta_{i} \quad$ Initial value of soil water content

$\theta_{s} \quad$ Field saturated soil water content

$\Delta H \quad$ Matric pressure head at the moving wetting front

$v$ hmin Minimum velocity for hillslope cells Lower value for the flow velocity in the hillslope cells

$v_{\text {hmax }}$ Maximum velocity for hillslope cells Upper value for the flow velocity in the hillslope cells

At Threshold area for river network It sets if a cell having contributing area $\mathrm{A}$ is a channel cell $(\mathrm{A} \geq \mathrm{At})$ or a hillslope cell $(\mathrm{A}<\mathrm{At})$

$\Delta t_{p} \quad$ Hyetograph time discretization Rainfall time resolution

$\Delta t_{\text {iuh }} \quad$ WFIUH and hydrograph $\quad$ WFIUH time resolution time discretization
It sets rainfall critical duration and cumulative depth. It determines the WFIUH basetime

the initial losses as percentage of the potential retention of soil

It sets the excess cumulative rainfall depth. It is assigned by default using empirical tables Green-Ampt equation parameter depending on soil type. It represents the initial value for the CN4GA procedure

Green-Ampt equation parameter depending on soil type Green-Ampt equation parameter depending on soil type

Green-Ampt equation parameter depending on soil type 
ferently imposed by users) the critical rainfall duration, its cumulative depth, and the WFIUH base-time. It is noteworthy that assuming the critical rainfall duration equal to the catchment concentration time follows the theoretic assumption that this choice causes the maximum peak discharge at the outlet compared to shorter or longer rainfall durations (Šraj et al., 2010). Accordingly, EBA4SUB set the critical rainfall duration equal to $T_{c}$ estimated by the Giandotti formula, which was developed considering basins with catchments area between $100 \mathrm{~km}^{2}$ and $1700 \mathrm{~km}^{2}$. Nevertheless, if different formulas are employed a strong variability for $T_{c}$ can arise, up to $500 \%$ (Grimaldi et al., 2012). Therefore, in this contribution, we used the following different formulas to evaluate $T_{c}$ for each case study: Department of Public Works California, Giandotti, Johnstone and Cross, Kirpich NRCS, and Viparelli. Their formulations are reported in Grimaldi et al. (2012) and are not included here for brevity. The range of $T_{c}$ was defined by the minimum and maximum of the obtained values, while their average was assumed as the reference value. Moreover, we recognize that the hypothesis of the maximum peak discharge caused by a rainfall with a duration equal to the catchment concentration time is debated in literature. Indeed, in many practical applications, rainfall durations 2-3 times larger than concentration time are used in order to maximize the peak discharge (Sikorska et al., 2017). In order to test such hypothesis, we investigate also two additional rainfall durations, respectively equal to 2 and 3 times the reference concentration time. In these latter tests we held fixed the catchment WFIUH time-base, i.e. we separate the rainfall duration from the catchment temporal response.

The parameters $\lambda$ and $\mathrm{CN}$ determine the cumulative excess rainfall. The initial abstraction value $\lambda$ was considered fixed and equal to 0.2 as prescribed by the original formulation, since EBA4US uses the official NRCS look up tables linking CN to soil type and land use. Regarding $\mathrm{CN}$, its reference value was assumed equal to the default one, estimated by EBA4SUB for each case study based on the specific soil-type and land-use maps. The $\mathrm{CN}$ range limiting-values were determined starting from the official NRCS look up tables. The reported $\mathrm{CN}$ variation ranges between a $20 \%$ difference for hydrologic group soil A (sand) and a 5\% for hydrologic group soil D (clay). AMC II condition, i.e. a moderate humidity for soil, was selected.

The parameters of Green-Ampt equation, $K_{s}, \Delta H, \theta_{i}$ and $\theta_{s}$, determine the excess rainfall temporal distribution. Only the last three were investigated, since CN4GA calibrates automatically an optimal value for $K_{S}$. The investigated values for $\Delta H$ and $\theta_{S}$ were assigned considering the Hydrologic Soil Group (HSG) of the specific case study, which was determined by using the available soil maps and considering the texture classes proposed by Rawls et al. (1982) for the soils classification. Fixed both the range and reference values for $\theta_{s}$ makes possible to settle those for $\theta_{i}$ as the median value of the interval between $\theta_{s}$ and residual saturation $\theta_{r}$, in agreement with the previous hypothesis of AMC II. NRCS HSG B (Vezza, Gornji Vakuf, Dittaino case studies) was considered formed by the texture classes loam (lower values for $\Delta H, \theta_{i}$ and $\theta_{s}$ ), silt loam (reference values for $\Delta H, \theta_{i}$ and $\theta_{s}$ ), and sandy clay loam (upper values for $\Delta H, \theta_{i}$ and $\theta_{s}$,), while NRCS HSG C (Abolabbas case study) was considered formed by the texture classes clay loam (lower values for $\Delta H, \theta_{i}$ and $\theta_{s}$ ), silty clay loam (reference values for $\Delta H, \theta_{i}$ and $\theta_{s}$ ), and sandy clay (upper values for $\Delta H, \theta_{i}$ and $\theta_{s}$ ). Each texture class, in synthesis, forms a lower, a reference and an upper condition for the three parameters considered together.

The parameters $v_{\text {hmin }}$ and $v_{h \max }$ define minimum and maximum values for the flow velocity in the hillslope cells. Indeed, the combined local slope and local land use could provide unrealistic val- ues for flow velocity due to the empirical nature of the formula, circumstance that could create problems in the definition of WFIUH. For this reason, minimum and maximum values of the hillslope velocity are fixed, so when the estimated value exceeds the assigned limits, the corresponding threshold value is adopted. In this study, lower, reference and upper values for vhmin and vhmax have been assigned thanks to previous studies and considering physical plausible values of the surface runoff.

Parameter $A_{t}$ represents the threshold area for the drainage network formation. A cell with a contributing area $A$ is considered laying in a channel cell if $A \geq A_{t}$ or laying on a hillslope cell if $A<A_{t}$. Therefore, the choice of the threshold affects the total number of pixels forming the channel and hillslope parts of the basin and reflect itself in modifying the flow velocity field as well as the WFIUH distribution. Lower, reference and upper values for these parameters were assigned considering results reported by Montgomery and Dietrich (1988).

Finally, $\Delta t_{p}$ and $\Delta t_{i u h}$ parameters represent the rainfall and WFIUH time resolution, which should have the same value in order to perform correctly the convolution integral. Different values for these two parameters affect both distributions of the rainfall, when hyetographs characterized by a variable rainfall intensity are selected, and of the discretized WFIUH. Regarding the range and reference values to adopt, in general it can be said that the time resolution should not be too small neither too large. If it is too small, unrealistic rainfall intensities values could be generated in the Chicago hyetograph; if it is too large, a limited number of discretization in both the hyetograph both the discretized WFIUH will be generated, especially for smaller catchments characterized by short concentration times. In the present analysis, lower, reference and upper values for these parameters were assigned considering experiences gained in previous EBA4SUB applications.

Table 4 reports in detail, for all the selected case studies, lower, reference and upper values for all the investigated input parameters. In the following analysis, the DDF obtained using the available rainfall data have been used, selecting return periods $(T)$ equal to $5,10,20,50$ and 100 years and assuming rectangular and symmetric Chicago hyetograph, respectively.

\section{Results and discussion}

In Figure 2 the range of the obtained peak discharges, $Q_{p}$, are shown. Figure 2 reports, for the assumed $T$, the range of $Q_{p}$ varying the single investigated parameters in the upper/lower condition as respect to the reference situation. A first comment from Figure 2 is related to the variation of $Q_{p}$ with the selection of the hyetograph shape. For all the investigated combinations of parameters, the Chicago hyetograph always provides higher values (in average, a $25 \%$ increment for $T=5$ years and a $34 \%$ increment for $T=100$ years) for all the case studies. This behaviour is consistent with recent literature. For instance, Wałęga (2016) investigated the impact of the hyetograph pattern on the peak discharge and reported that the rainfall temporal distribution had up to $20 \%$ impact on the differences in peak discharges, while Oliveira and Stolpa (2003) determined that constant-intensity rainfall generates significantly lower peak flows compared to other hyetograph shapes.

Concerning the influence of investigated parameters different effects emerge. For all the case studies here considered, $\mathrm{CN}$ and $T_{c}$ determine the largest variation from the reference condition. This influence is expected as $\mathrm{CN}$ and $T_{c}$ are crucial in assessing the design peak discharge with EBA4SUB, as preliminarily noted in 
Table 4. Lower, reference and upper values for input parameters.

\begin{tabular}{|c|c|c|c|}
\hline \multicolumn{4}{|c|}{ Vezza case study } \\
\hline Parameter & Lower & Réference & Upper \\
\hline $\mathrm{T}_{\mathrm{c}}(\mathrm{h})$ & 4 & 8 & 10 \\
\hline \multirow[t]{2}{*}{$\mathrm{CN}(-)$} & 65 & 70 & 75 \\
\hline & Loam & $\begin{array}{l}\text { il parameters } \\
\text { Silt loam }\end{array}$ & Sandy clay loam \\
\hline$\Delta \mathrm{H}(\mathrm{mm})$ & 401.2 & 508.7 & 594.1 \\
\hline$\theta_{\mathrm{i}}(-)$ & 0.231 & 0.251 & 0.199 \\
\hline$\theta_{\mathrm{s}}(-)$ & 0.434 & 0.486 & 0.330 \\
\hline$v_{\mathrm{hmin}}(\mathrm{m} / \mathrm{s})$ & 0.05 & 0.1 & 0.5 \\
\hline$v_{\mathrm{hmax}}(\mathrm{m} / \mathrm{s})$ & 0.5 & 1 & 2 \\
\hline At $\left(\mathrm{km}^{2}\right)$ & 0.5 & 1 & 1.5 \\
\hline$\Delta t_{p}(\min ), \Delta t_{i u h}(\min )$ & 15 & 30 & 60 \\
\hline \multicolumn{4}{|c|}{ Abolabbas case study } \\
\hline Parameter & Lower & Reference & Upper \\
\hline $\mathrm{T}_{\mathrm{c}}(\mathrm{h})$ & 3 & 5 & 7 \\
\hline \multirow[t]{2}{*}{ CN (-) } & 70 & 75 & 80 \\
\hline & Clay loam & $\begin{array}{l}\text { sil parameters } \\
\text { ilty clay loam }\end{array}$ & Sandy clay \\
\hline$\Delta \mathrm{H}(\mathrm{mm})$ & 564.3 & 703.3 & 794.8 \\
\hline$\theta_{\mathrm{i}}(-)$ & 0.233 & 0.236 & 0.215 \\
\hline$\theta_{\mathrm{s}}(-)$ & 0.390 & 0.432 & 0.321 \\
\hline$V_{\mathrm{hmin}}(\mathrm{m} / \mathrm{s})$ & 0.05 & 0.1 & 0.5 \\
\hline$v_{\mathrm{hmax}}(\mathrm{m} / \mathrm{s})$ & 0.5 & 1 & 2 \\
\hline At $\left(\mathrm{km}^{2}\right)$ & 0.5 & 1 & 1.5 \\
\hline$\Delta t_{p}(\min ), \Delta t_{\text {iuh }}(\min )$ & 15 & 30 & 60 \\
\hline \multicolumn{4}{|c|}{ Gornji Vakuf case study } \\
\hline $\mathrm{T}_{\mathrm{c}}(\mathrm{h})$ & 3 & 5 & 7 \\
\hline \multirow[t]{2}{*}{$\mathrm{CN}(-)$} & 55 & 60 & 65 \\
\hline & Loam & $\begin{array}{l}\text { il parameters } \\
\text { Silt loam }\end{array}$ & Sandy clay loam \\
\hline$\Delta \mathrm{H}(\mathrm{mm})$ & 401.2 & 508.7 & 594.1 \\
\hline$\theta_{\mathrm{i}}(-)$ & 0.231 & 0.251 & 0.199 \\
\hline$\theta_{\mathrm{S}}(-)$ & 0.434 & 0.486 & 0.330 \\
\hline$V_{\mathrm{hmin}}(\mathrm{m} / \mathrm{s})$ & 0.05 & 0.1 & 0.5 \\
\hline$v_{\mathrm{hmax}}(\mathrm{m} / \mathrm{s})$ & 0.5 & 1 & 2 \\
\hline At $\left(\mathrm{km}^{2}\right)$ & 0.5 & 1 & 1.5 \\
\hline$\Delta t_{p}(\min ), \Delta t_{\text {iuh }}(\min )$ & 15 & 30 & 60 \\
\hline Parameter & Lower & $\begin{array}{l}\text { study } \\
\text { Reference }\end{array}$ & Upper \\
\hline $\mathrm{T}_{\mathrm{c}}(\mathrm{h})$ & 6 & 8 & 10 \\
\hline \multirow[t]{2}{*}{ CN (-) } & 65 & 70 & 75 \\
\hline & Loam & $\begin{array}{l}\text { il parameters } \\
\text { Silt loam }\end{array}$ & Sandy clay loam \\
\hline$\Delta H(\mathrm{~mm})$ & 401.2 & 508.7 & 594.1 \\
\hline$\theta_{\mathrm{i}}(-)$ & 0.231 & 0.251 & 0.199 \\
\hline$\theta_{\mathrm{s}}(-)$ & 0.434 & 0.486 & 0.330 \\
\hline$V_{\mathrm{hmin}}(\mathrm{m} / \mathrm{s})$ & 0.05 & 0.1 & 0.5 \\
\hline$v_{\mathrm{hmax}}(\mathrm{m} / \mathrm{s})$ & 0.5 & 1 & 2 \\
\hline At $\left(\mathrm{km}^{2}\right)$ & 0.5 & 1 & 1.5 \\
\hline$\Delta t_{p}(\min ), \Delta t_{\text {iuh }}(\min )$ & 15 & 30 & 60 \\
\hline
\end{tabular}


Piscopia et al. (2015). In detail, $\mathrm{CN}$ is generally the most impacting parameter, followed by $T_{c}$ (Figure 2)

It is interesting also to note the particular combinations where the WFIUH is calibrated on the reference $T_{c}$, while the rainfall duration is set as 2 or 3 times larger than $T_{c}$. Using the rectangular hyetograph we found, for the case studies of Vezza, Abolabbas and Dittaino, a decrease of peak discharge respect to the reference condition, whereas, for Gornji Vakuf watershed, we obtained an increase of peak discharge. The former behaviour was expected because it is related to the DDF distribution. Actually, the increase in the cumulative rainfall depth is proportionally smaller than the increase of rainfall duration and, accordingly, a decrease of the rainfall intensity occurs, giving therefore a smaller peak discharge. The exception of latter behaviour presented by Gornji Vakuf watershed is quite unexpected and counter intuitive. The basin is characterized by a $\mathrm{CN}$ lower than those of the other basins. It is well
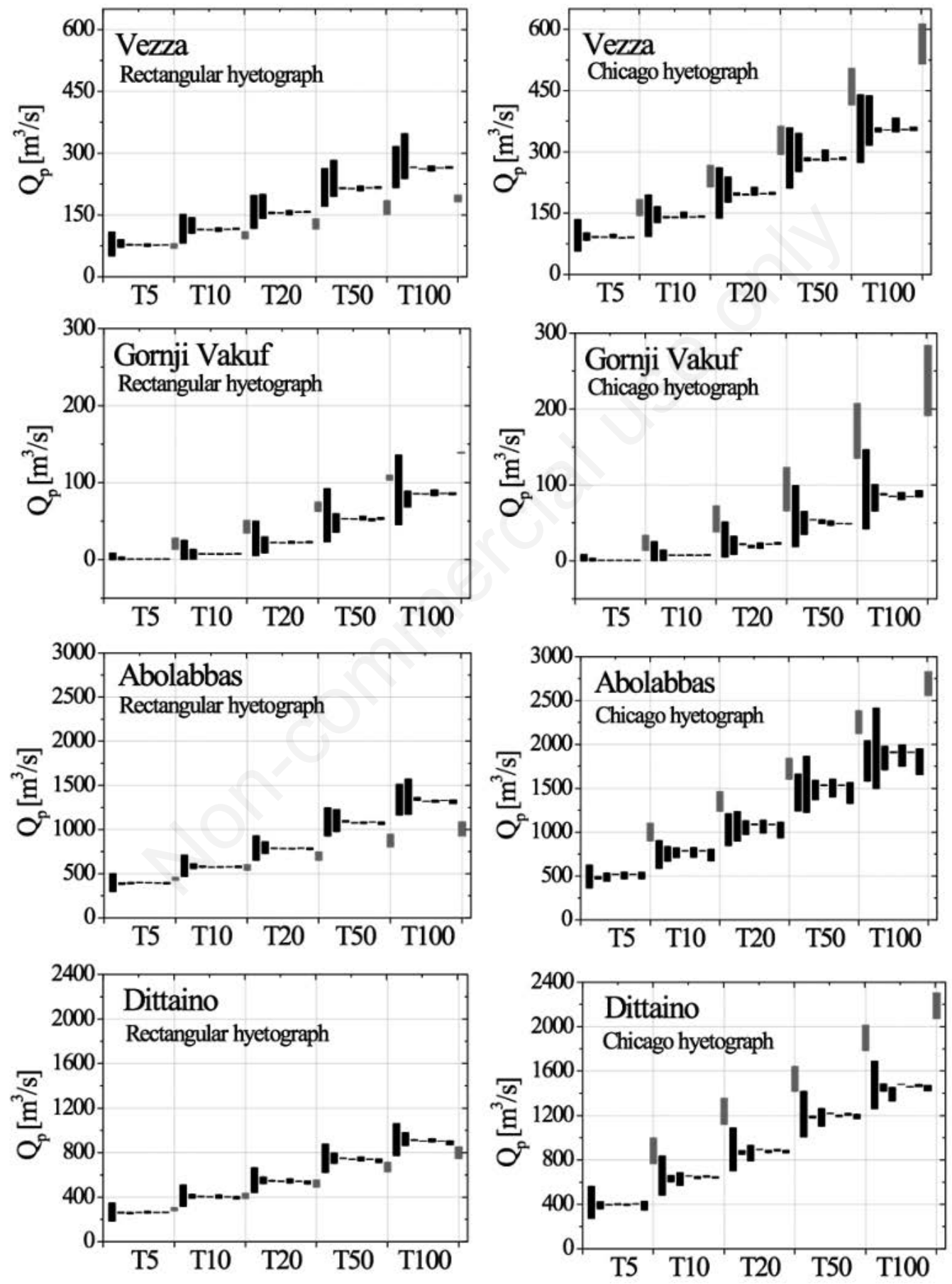

Figure 2. $Q_{p}-T$ relationships. For each $T$ we report the range of modelled $Q p$ corresponding to the following parameters in the upper/lower condition (from left to right): $\mathrm{CN}, T_{c}, D t$, Soil, $A_{t}, v_{\text {mmax }}$, v $v_{\text {mmin }}$. The last boxplot (in grey) is related to the case where WFIUH time-base is equal to $T_{c}$ in reference condition and the critical duration is varied $\left(\mathrm{t}=2-3 T_{c}\right)$. 
known that, by increasing the cumulative rainfall depth, the cumulative excess rainfall grows at a rate depending on $\mathrm{CN}$ : lower is the $\mathrm{CN}$ that more retarded is the runoff growth. This behaviour is joint with initial abstraction, which is independent from the cumulate rainfall depth. Therefore, for Gornji Vakuf watershed, a higher rainfall duration gives a greater cumulative rainfall depth, which in turn gives a greater increase in cumulate rainfall excess compared to other case-studies, and finally an increased peak discharge.
Conversely, adopting the Chicago hyetograph we found that an increase in rainfall duration produces in each case study a relevant increase of peak discharge. Also this behaviour was expected as Chicago hyetograph, by definition, gives critical rainfall for each partial duration. Assuming a symmetric shape of hyetograph, an increase of rainfall duration retards the occurrence of the rainfall peak and therefore only the first part of the event is lost by initial abstraction, preserving the entire rainfall peak for a complete
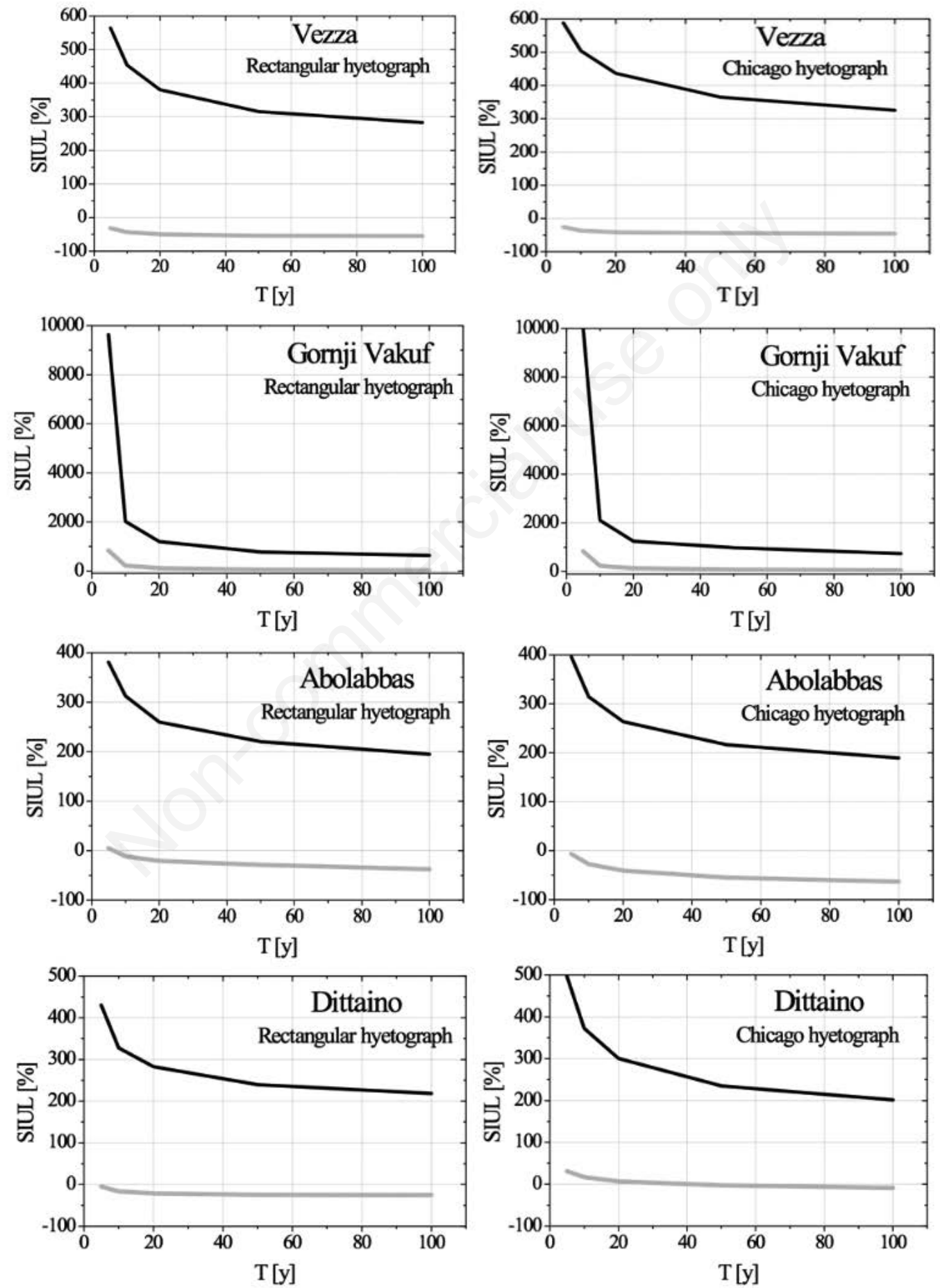

Figure 3. SIUL. Black line: CN parameter. Grey line: $T_{c}$ parameter. 
runoff. All the other investigated parameters, excluded $\mathrm{CN}$ and $T_{c}$, gives more limited deviation from the reference conditions.

In order to quantify such variations we refer to the SIUL index that is shown in Figure 3 (for $\mathrm{CN}$ and $T_{c}$ parameters) and in Figure 4 (for $v_{h \max }, v_{h \min }, A_{t}$, and $\Delta t_{p} / \Delta t_{i u h}$ parameters). In Figures 3 and 4 we do not report the results related to $t$ equal to 2 or 3 times $T_{c}$, for sake of clearness. Moreover, for brevity, also the results related to soil parameters are not included, because in such circumstances the SIUL denumerator cannot be defined with 3 sub-parameters $\left(\Delta H, \theta_{i}\right.$ and $\theta_{s}$ ) that should have been considered separately. The curves depicted in Figures 3 and 4 clearly confirm the different relevance of the investigated parameters. $\mathrm{CN}$ is the more influencing parameter, with variations expressed by SIUL that decrease with return period and that, for $T=100$ years, arrive at $282 \% / 325 \%$ for Vezza, $630 \% / 738 \%$ for Gornji Vakuf, $195 \% / 189 \%$ for Abolabbas and $218 \% / 201 \%$ for Dittaino, assuming rectangular and Chicago
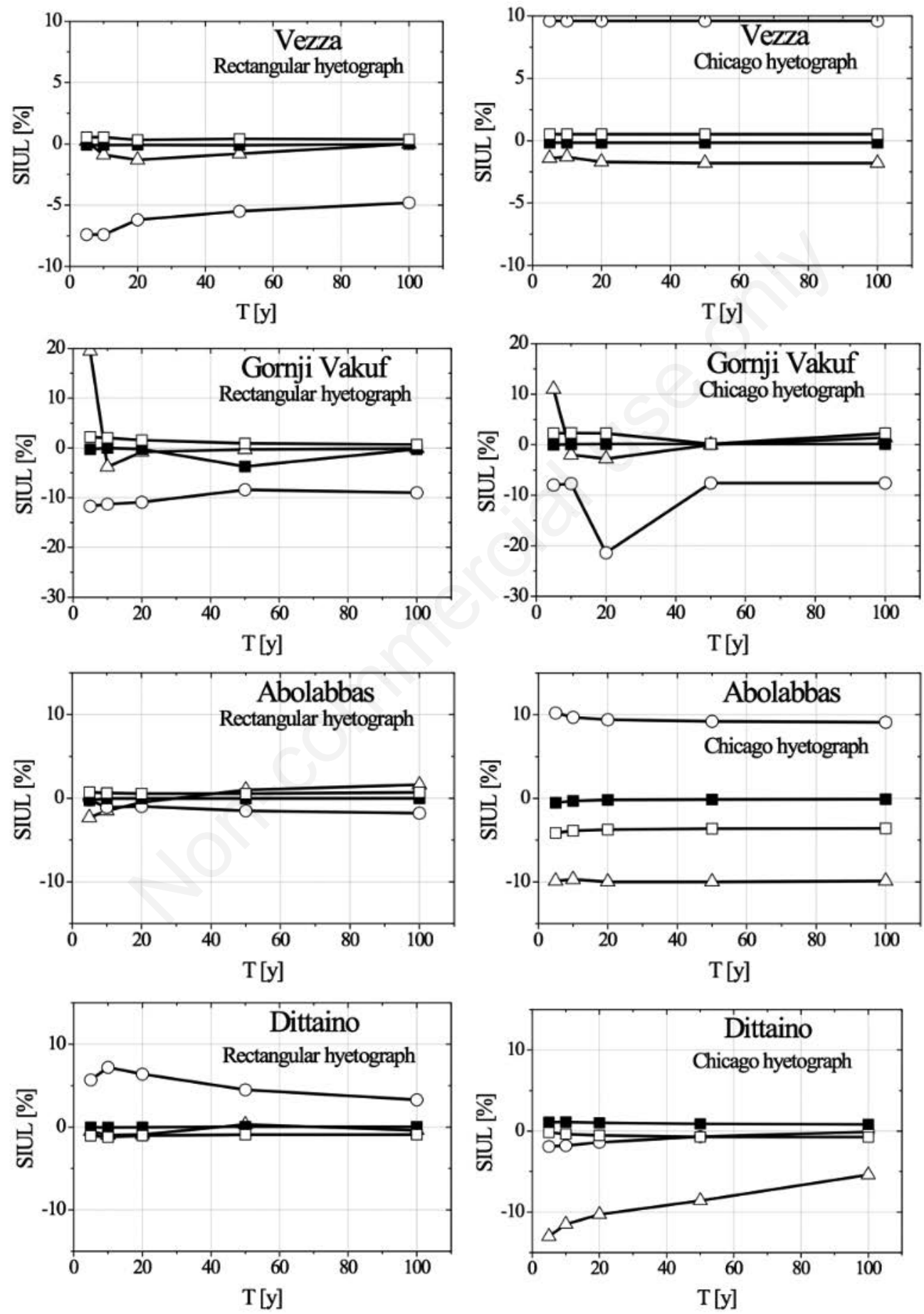

Figure 4. SIUL. Black line with triangles: $D_{t}$ parameter. Black line with circles: $A_{t}$ parameter. Black line with black boxes: $v_{h m a x}$ parameter. Black line with white boxes: vbmin parameter. 
hyetograph, respectively. Based on the classification proposed by Feki et al. (2018), the sensitivity of the model to such input parameter can be classified as very high. Concerning the influence of $T_{C}$, we generally observed a decrease with $T$ even if this behaviour in not unique and, for $T=100$ years, SIUL is $-45 \% /-55 \%$ for Vezza, $30 \% / 51 \%$ for Gornji Vakuf, $-37 \% /-63 \%$ for Abolabbas and $25 \% /-9 \%$ for Dittaino, assuming rectangular and Chicago hyetograph, respectively. Based on the classification proposed by Feki et al. (2018), the sensitivity of the model to such input parameter can be classified as high. The third and fourth parameters ( $A_{t}$ and $\left.\Delta t_{p} / \Delta t_{i u h}\right)$ are almost irrelevant; indeed, the differences for SIUL are in the range $-9 \% / 9 \%$, and $-9 \% / 2 \%$, respectively. The same behaviour is found for the kinematic parameters that vary in the range $-4 \% / 2 \%$, although these values increase for shorter $T$. Based on the classification proposed by Feki et al. (2018), the sensitivity of the model to such input parameters can be classified from small to negligible.

In conclusion, we can confirm what preliminarily expressed in Piscopia et al. (2015), i.e. that EBA4SUB framework is characterized by primary parameters, such as $\mathrm{CN}$ and $T_{c}$, and secondary parameters. Primary parameters have a predominant role in EBA4SUB and their values should be assigned carefully using empirical formulas or tables and could be calibrated if an adequate number of observed rainfall-runoff events is available. Ancillary parameters cause a limited effect on the output, i.e. the design peak discharge. Consequently, these parameters could be easily assigned using the values suggested by the present work. Finally, it is confirmed the critical role exerted by the hyetograph shape, with differences till to $30 \%$ for the Chicago hyetograph, confirming previous literature works.

One final remark is related to the estimation of hydrograph total volumes, which is crucial in many applications (e.g. flooded area delineation). In EBA4SUB, the total volume is influenced only by $T_{c}$ (affecting the gross rainfall volume) and by $\mathrm{CN}$ (affecting the excess rainfall volume). The other input parameters affect the WFIUH shape and hence the peak discharge, but not the hydrograph total volume. When considering $\mathrm{CN}$ as input parameter, the obtained results on the modelled design hydrographs restitute a SIUL index related to total volume equal to $517 \%$ for Vezza case study, to $3000 \%$ for Gornji Vakuf case study, to $393 \%$ for Abolabbas case study, and to $440 \%$ for Dittaino case study, averaging the results for every investigated $T$. When considering $T_{c}$ as input parameter, the obtained results on the modelled design hydrographs restitute a SIUL index related to total volume equal to $75 \%$ for Vezza case study, to $266 \%$ for Gornji Vakuf case study, to $103 \%$ for Abolabbas case study, and to $68 \%$ for Dittaino case study, averaging the results for every investigated $T$. Based again on the classification proposed by Feki et al. (2018), the sensitivity of the model to $\mathrm{CN}$ can be classified as very high, while the sensitivity of the model to $T_{c}$ can be classified as high for two case studies and very high for the other two case studies. We can conclude that also concerning the total volume the $\mathrm{CN}$ is the most important parameter, followed by $T_{c}$.

\section{Conclusions}

The design hydrograph and related peak discharge estimation for small and ungauged watersheds is a common and crucial problem in practical hydrology. Different strategies can be adopted, from regionalization approaches to the application of empirical formulas. Conceptual rainfall-runoff models are particularly appealing since they mimic in a simplified form the complex processes, from infiltration to flow routing, occurring on the catchment. Recently, the EBA4SUB empirical-conceptual rainfallrunoff model has been proposed. It consists in three modules (gross rainfall estimation, excess rainfall estimation, rainfallrunoff transformation) and it is characterized by different input parameters. In this paper we investigated four case-study catchments, with contributing areas ranging from $167 \mathrm{~km}^{2}$ to $397 \mathrm{~km}^{2}$ and different geomorphological properties, and we developed a sensitivity analysis with the aim of assessing the relevance of model input parameters on the design peak discharge.

Results showed that the most relevant parameter is the $\mathrm{CN}$, followed by the concentration time. These two parameters should carefully be assessed in order to apply the model, eventually pursuing monitoring approaches or using, if available, observed rainfall-runoff events. The other parameters in order of relevance are the threshold area value for estimating the drainage network, the rainfall and the width function instantaneous unit hydrograph discretization time step, and the kinematic parameters (minimum and maximum hillslope surface flow velocity). Such parameters can be considered ancillary, and we identified default values that can be taken as reference and adopted in practice.

\section{References}

Clark GE, Ahn K-H, Palmer RN. 2017. Assessing a regressionbased regionalization approach to ungauged sites with various hydrologic models in a forested catchment in the northeastern United States. J. Hydrol. Engine. 22:05017027.

Feki M, Ravazzani G, Ceppi A, Milleo G, Mancini M. 2018. Impact of infiltration process modeling on soil water content simulations for irrigation management. Water 10:850.

Gądek WJ, Baziak B., Tokarczyk T. 2017. Nonparametric design hydrograph in the gauged cross sections of the Vistula and Odra basin. Meteorol. Hydrol. Water Manage. 5:53-61.

Grimaldi S, Petroselli A, Tauro F, Porfiri M. 2012. Time of concentration: a paradox in modern hydrology. Hydrol. Sci. J. 57:217-28.

Gumindoga W, Rwasoka DT, Nhapi I, Dube T. 2017. Ungauged runoff simulation in Upper Manyame Catchment, Zimbabwe: Application of the HEC-HMS model. J. Physics Chem. Earth 100:371e382.

Kittel C, Nielsen K, Tøttrup C, Bauer-Gottwein P. 2018. Informing a hydrological model of the Ogooué with multi-mission remote sensing data. Hydrol. Earth Syst. Sci. 22:1453-72.

Młyński D, Petroselli A, Wałęga A. 2018. Flood frequency analysis by an event-based rainfall-Runoff model in selected catchments of southern Poland. Soil Water Res. 13:170-6.

Montgomery DR, Dietrich WE. 1988. Where do channels begin? Nature 336:232-4.

Nardi F, Annis A, Biscarini C. 2018. On the impact of urbanization on flood hydrology of small ungauged basins: The case study of the Tiber river tributary network within the city of Rome. J. Flood Risk Manage. 11:S594-603.

NRCS (Natural Resources Conservation Service). 2008. National engineering handbook - part 630, Hydrology. U.S. Department of Agriculture, Washington, DC, USA.

Oliveira F, Stolpa D. 2003. Effect of the storm hyetograph duration and shape on the watershed response. In: Proc. 82nd Annual Meeting of the Transportation Research Board. Washington DC, USA.

Petroselli A, Asgharinia S., Sabzevari T, Saghafian B. 2019c. 
Comparison of design hydrograph estimation methods for ungauged basins in Iran. Hydrol. Sci. J. [In press].

Petroselli A, Fernandez Alvarez A. 2012. The flat area issue in DEMs and its consequences on the rainfall-runoff modeling. GISci. Remote Sensing 49:711-34.

Petroselli A, Grimaldi S. 2018. Design hydrograph estimation in small and fully ungauged basins: a preliminary assessment of the EBA4SUB framework. J. Flood Risk Manage. 11:S197-210.

Petroselli A, Mulaomerović-Šeta A, Lozančić Ž. 2019b. A comparison of methodologies for design peak discharge estimation in selected catchments of Bosnia and Herzegovina. Gradjevinar, 71:729-39.

Petroselli A, Vojtek M, Vojteková J. 2019a. Flood mapping in small ungauged basins: a comparison of different approaches for two case studies in Slovakia. Hydrol. Res. 50:379-92.

Pinheiro VB, Naghettini M, 2013. Calibration of the parameters of a rainfall-runoff model in ungauged basins using synthetic flow duration curves as estimated by regional analysis. J. Hydrol. Engine. 18:1617-26.

Piscopia R, Petroselli A, Grimaldi S. 2015. A software package for the prediction of design flood hydrograph in small and ungauged basins. J. Agricult. Engine. XLVI:74-84.

Razavi T, Coulibaly P. 2017. An evaluation of regionalization and watershed classification schemes for continuous daily streamflow prediction in ungauged watersheds. Canad. Water Resour. J. 42:2-20.

Rawls WJ, Brakensiek CL, Saxton KE. 1982. Estimation of soil water properties. Trans. ASAE 25:1316-20, 1328.

Recanatesi F, Petroselli A, Ripa MN, Leone A. 2017. Assessment of stormwater runoff management practices and BMPs under soil sealing: a study case in a peri-urban watershed of the metropolitan area of Rome (Italy). J. Environ. Manage. 201:6-18.

Sabzevari T. 2017. Runoff prediction in ungauged catchments using the gamma dimensionless time-area method. Arab. J. Geosci. 10:131.

Sikorska AE, Viviroli D, Seibert J. 2017. Effective precipitation duration for runoff peaks based on catchment modelling. J. Hydrol. 556:510-22.

Sivapalan M, Takeuchi K, Franks SW, Gupta VK, Karambiri H, Lakshmi V, Liang X, McDonnell JJ, Mendiondo EM, O'Connell PE, Oki T, Pomeroy JW, Schertzer D, Uhlenbrook S, Zehe E. 2003. IAHS decade on Predictions in Ungauged Basins (PUB), 2003-2012: shaping an exciting future for the hydrological sciences. Hydrol. Sci. J. 48:857-80.

Šraj M, Dirnbek L, Brilly M. 2010. The influence of effective rainfall on modelled runoff hydrograph. J. Hydrol. Hydromech. 58:3-14.

Vojtek M, Vojteková J. 2016. Flood hazard and flood risk assessment at the local spatial scale: a case study. Geomat. Natural Hazards Risk 7:1973-92.

Vojtek M, Petroselli A, Vojteková J, Ashgarinia S. 2019. Flood inundation mapping in small and ungauged basins: sensitivity analysis using the EBA4SUB and HEC-RAS modeling approach. Hydrol. Res. 50:1002-19.

Wałęga A. 2016. The importance of calibration parameters on the accuracy of the floods description in the Snyder's model. J. Water Land Develop. 28:19-25.

Wałęga A, Amatya DM, Caldwell P, Marion D, Panda S. 2020. Assessment of storm direct runoff and peak flow rates using improved SCS-CN models for selected forested watersheds in the Southeastern United States. J. Hydrol. Regional Stud. 27:100645

Xu Q, Chen J, Peart MR, Ng C, Hau BCH, Law WY, 2018. Exploration of severities of rainfall and runoff extremes in ungauged catchments: A case study of Lai Chi Wo in Hong Kong, China. J. Sci. Total Environ. 634:640-9. 